\title{
CONSIDERATIONS REGARDING SYSTEMIC INTERACTION OF LAW WITH OTHER SOCIAL NORMATIVE SUBSYSTEMS
}

\author{
C.R.D. Butculescu \\ S.M. Florea
}

\section{Claudiu Ramon D. Butculescu}

“Acad. Andrei Rădulescu” Legal Research Institute, Romanian Academy, Bucharest, Romania *Correspondence: Claudiu Ramon D. Butculescu, 4 Bela Bartok St., $2^{\text {nd }}$ District, Bucharest, Romania

E-mail: butculescu@yahoo.com

\section{Sorina Maria Florea}

The Romanian Society of Criminology and Criminalistics Bucharest, Romania *Correspondence: Sorina Maria Florea, 25 Livezilor St., Pantelimon, Ilfov County E-mail: sorinamflorea@gmail.com

\section{Abstract}

This article tackles the issue of systemic interaction between various normative systems. As such, it addresses and analyses the system of law from the perspective the general systems theory. More than that, the paper analyses the links and interactions between various normative systems, called sub-systems in the paper, and the division of law, namely public law and private law.

\section{Keywords: Systems, legal cultures, law, normative systems}

\section{Introduction}

In most works that analyze the law and legal theories, law is generally defined as a complex of regulations that govern the human society.In the doctrine, law was further defined as an aggregate of general regulations, abstract and impersonal, emanating from the public authority, as an entity invested with powers concerning regulations or decisions of administrative authorities ${ }^{1}$.

Law may be analyzed also through the systemic perspective. Also, the interactions between law and the others systems that form the bigger social normative system may be analyzed thoroughly, using systemic approaches.

\section{Law as a system within the General Systems Theory}

According to the general theory of systems, a system should be analyzed as a whole, as well as through its non-linear interactions of internal or external nature. This paper continues researches made prior, regarding the systemic structure of $\mathrm{law}^{2}$, the systemic interactions of law and other normative systems ${ }^{3}$ andsystemic approach to legal cultures.

In Legal theory, the system of law is depicted as a normative system, which finds its place and application within the national and international systems. Both in internal and international systems, the law interact with other systems, such as morality, religion, customary rules or systems of social coexistence.

\footnotetext{
${ }^{1}$ Sofia Popescu, Teoria generală a dreptului, Lumina Lex Publishing House, Bucharest, 2003, p.123.

${ }^{2}$ C. D. Butculescu, Cuantica dreptului - o nouă perspectivă în percepția fenomenelor juridice, in vol. "Justiție, Stat de drept și cultură juridică”, Universul Juridic Publishing House, Bucharest, 2011, pp. 96-104.

${ }^{3}$ C. D. Butculescu, Short considerations regarding the system of law from the perspective of General Systems Theory, Journal of Legal Studies, year VII, no. 3-4/2012, pp. 129 - 134.
} 
Law, as seen in legal theory is also comprised of two major divisions, namely: public law, which encompasses all the branches of law that regulate public interests, and private law, which is formed out of those branches of law that govern private interests of persons.

Law as a system could have the following characteristics ${ }^{4}$ : a) open system; b non-linear system); c) stable system; d) system characterized by moderate entropy.

The stability of the law is nowadays particularly precarious, being conditioned by several factors, such as political stability, respect for the principles of the separation of powers ${ }^{5}$, the makers of the right configuration, etc.

In the other works cited above, the structure of the law, seen from a systemic perspective was taken into consideration and also certain interactions between the law, as a whole system and the other social normative sub-systems were analyzes. However, we are now considering researching the matter further, as this paper tries to briefly analyze the specific interactions between the social normative sub-systems, as moral, rules of social conduct, religion and the divisions of law: public and private law.

Within the human society, there are at least 6 regulatory operating systems. If, however, we relate these systems to the society itself, then they become sub-systems in relation to the social system.

\section{Short presentation of the social normative sub-systems}

As it has been pointed out in the specialized literature ${ }^{6}$, the normative legal system interacts with other regulatory systems existing within the society. The law itself is a discipline with a social character which regulates certain relationships between people, through social relationships specific to its own branches: civil, criminal, administrative, commercial etc.

Thus, in the systemic approach, we may analyze the currents values of diversification which occur inter-systemically and intra-systemically. The concept is not new, having been approached in the past by the sociologists of law ${ }^{7}$.

In addition to the law, we should also mention the other normative systems that find their application in society.

The moral system is a system of rules that has a high level of cohesion, covering all the rules deemed mandatory, under the penalty of public odium. Between law and moral, there are both differences and similarities. The most important similarities are that both the law and the rules of morality address themselves to social collectivities, and are also based on paradigms applicable to precise factual realities. Morality differs from law through its sources and its purposes.

Morality is a system mostly closed. Moral rules are specific to a certain social system and the interactions taking place in their great majority within the system, not outside it. Moral system also is characterized by linearity and stability.

Law, as a whole, may present moral features, because most of its elements, especially the laws retain such characteristics. Nevertheless, there are specific systemic properties, which are pertaining only to law and are different from the features of its components ${ }^{8}$.

Most scholars admit the existence of a close link between law and moral. The principles of good, righteousness, justice and truth belong to the moral system, but are protected and promoted by law regulations. Both law and moral are made from a complex of rules of conduct, although the moral precepts are based on immutable truths, while legal norms point towards relative phenomena, resulted from the will and intelligence of people. Moreover, while moral

\footnotetext{
${ }^{4}$ C. D. Butculescu, Cuanticadreptului - o nouă perspectivă în percepția fenomenelor juridice, în vol. "Justiție, Stat de drept și cultură juridică”, Universul Juridic Bucharest, 2011, p. 98.

${ }^{5}$ E. Ciongaru, Securitatea juridică în statul de drept - concept, in volumul Sesiunii ştiinţifice a Institutului de Cercetări Juridice, 2012, Universul Juridic Bucharest, 2013, p. 607.

${ }^{6}$ Sofia Popescu, Teoria generală a dreptului, Lumina Lex Bucharest, 2003, p.23.

${ }^{7}$ V. Ferrari, Note sull'alternativa del diritto contemporano, Sociologia del diritto, Revista quadrimente fondata da Renato Treves, XX/1993/1, p. 23.

${ }^{8}$ A. F. Măgureanu, Principiile generale ale dreptului, Universul Juridic Bucharest, 2011, p. 188.
} 


\section{C.R.D. Butculescu S.M. Florea}

norms guide people toward the fulfillment of the moral good, law does not regard the human person in its supposed perfection, but the everyday individual that shares a permanent connection to its peers 9 .

The social rules of conduct are conditional rules that emanate from conventional sources ${ }^{10}$. They include acomplexof precepts that lead the individual to better his life in the community, without negatively influencing the life of the others.

The social rules of conduct must be considered as an open system, constantly changing. The derogation from the rules of social conduct may attract some negative opinions, but when these are exceeded, there is a possibility the incidence of moral system, which is much more strictly ${ }^{11}$.

Customs or habits, as they are known in the legal world constitute a unique system in social life. Custom is based on a specific consuetude ${ }^{12}$, which involves a long and continuous practice. When such consuetudes acquire the appearance of mandatory norms, they become habits or customs in the legal sense.

Customary systems may be considered as a semi-open system, which allows certain loans. The customary system also is considered a linear system.

The technical regulations may also be envisioned as a normative system, which presents many differentiations from other legal systems presented. They represent today a set of technical rules which, although they do not always have a specific mandatory character similar to the system of law, are almost always mandatory by default. However, the technical standards have had, since their inception, an almost secret character ${ }^{13}$.

The system of technical regulations was historically considered a closed system. However, as science evolved, this system became more and more open and is today perhaps the most dynamic of the six analyzed in this paper.

Religion may not be considered a complete normative system, because it does not meet all the conditions to be considered a full normative system. Nevertheless, it interacts closely with other normative systems. In some States, religion may even overlap in certain situations over the normative system of law.

At the same time, over history, the relationship between law and religion appears as unavoidable, substantially influencing the legal cultures. The religious precepts appear as foundation of the legal systems from all periods of time and from all the peoples. Even more so, even today there still are legal systems whose main source is religion, like the Muslim legal system $^{14}$.

Religion must be analyzed as a closed system. This is no doubt due to the fact that most religions contain truths that are revealed by specific deities. In these circumstances, the imports of information would probably be hindered by the absolute character of such truths.

Another sub-system is the legal culture, which may be seen as a system that interacts with the others or as an interphase of the law system, facilitating communication within the social normative system. Legal culture could be considered as a partially stable system and non-linear ${ }^{15}$.

\footnotetext{
${ }^{9}$ Andreea Drăghici, Ramona Duminică, "Convergences and distinctions between moral and juridical order", in Agora International Journal of Juridical Sciences, no. 2/2011, available on www.juridicaljournal.univagora.ro.

10 M. Tutunaru, R. Morega, C. Popescu, Drept constituţional şi instituţii politice, Scrisul românesc Publishing House, Bucharest, 2014, p. 26.

${ }^{11}$ M. Tutunaru, R. Morega, C. Popescu, op. cit., p. 27.

${ }^{12}$ E. Ciongaru, Usages - the legal regime in new civil code, in volume of The International Conference- CKS 2013

- Challenges of the Knowledge Society, "Nicolae Titulescu" University Bucharest, Prouniversitaria Publishing House, 2013, pp. 206-207.

${ }^{13}$ M. G. Losano, Marile sisteme juridice. Introducere în dreptul european și extraeuropean, All Beck Publishing House, Bucharest, 2005, p. 43

${ }^{14}$ Ramona Duminică, The divine foundation of the law, in Agora International Journal of Juridical Sciences, no. 2/2011, available on www.juridicaljournal.univagora.ro.

${ }^{15}$ C. D. Butculescu, A systemic approach to legal cultures, in vol. "La Metamorphose de l'Etat en Europe", Universul Juridic Publishing House, Bucharest, 2010, p. 85.
} 


\section{subsystems}

Interactions between the divisions of law, as systems and the other social normative

The law and the other subsystems of the social normative system, respectively: the moral system, the customary system, the legal cultures system, the rules of conduct system, religion and the technical norms system permanently interact one with another, determining changes in each system or subsystem.

In its relation with the moral system, it may appear that public law is more closely influenced by it, than private law. Most punitive sanctions originate within the moral system and have been taken, processed and improved by the penal law. Of course, the reversibility of the private law is also a principle strongly related to moral, as any disturbance of equilibrium calls for a restauration, and as we know, all systems tend to an equilibrium state.

The customary system, on the other hand, does not interact very much with the public law division. The public norms are usually imperative and must be upheld to the letter. Still, in civil law, there are regulations related to custom as a source of law, and even the Romanian Civil Law sometimes points to the custom of the land, as seen in article 613 or the Romanian Civil Code, which mentions the law, the planning certificate or the custom of the land, as sources of law.

The rules of social conduct have a profound impact on both private and public law. Within the field of public law, good faith is essential in analyzing various cases and imposing sanctions. In private law, there are also such influences to be found. For instance, in the article 1.272 of the Romanian Civil Code stipulates that a valid contract binds the parties to all the effects that law, custom and equity provide for such contract, with regard to its nature. In this case, equity may be considered as an element from the system of the rules of conduct. In the Romanian Civil Procedure Code, the judge himself may deliberate according to equity, in certain cases, as it is stipulated in article 5, para (3) and article 22, para (7).

The technical norms also influence the divisions of law. Most penal cases resort to technical expertise in order to find an appropriate solution to cases. The same may be said in the field of private law, where most real estate lawsuits depend on cadastral expertise.

The religion has had a significant influence on the development of both private and public law. Most regulations that are in force today, in private law, come from Roman Law, but this norms were also used by Canon Law. The principles that are the basis of the public law also find their roots in religious texts. For example, the Ten Commandments contain a series of biblical principles that contain both instructions and prohibitions against murder, theft and so on.

\section{Conclusions}

As we have shown in this paper, the punctual analysis of the interactions between various social normative subsystems and the two divisions of the law allow for a more accurate depiction of the dynamics that move the legal systems. When the interactions between such subsystems and the division of public law and/or private law are analyzed, the results seem different from the analysis of the interactions between the same subsystems and law, as a whole system. Certainly, the current paper constitutes only the beginning of further researches in this area. Hopefully, these researches will help us consolidate our knowledge in the field of systemic analysis of law.

\section{Bibliography}

- Tutunaru M., Morega R., Popescu C., Drept constituţional şi instituţii politice, Scrisul Românesc, Publishing House, Craiova, 2014;

- Ciongaru E., Usages - the legal regime in new civil code, in volume of The International Conference- CKS 2013 - Challenges of the Knowledge Society, Nicolae Titulescu University Bucharest, Prouniversitaria Publishing House, 2013; 


\section{C.R.D. Butculescu S.M. Florea}

- Ciongaru E., Securitatea juridică în statul de drept - concept, in volumul Sesiunii ştiinţifice a Institutului de Cercetări Juridice, 2013, Universul Juridic PublishingHouse, Bucharest, 2013;

- Butculescu C. D., Short considerations regarding the system of law from the perspective of General Systems Theory, pp. 129 - 134, Journal of Legal Studies, year VII, no. 3-4/2012;

- Butculescu C. D., Cuanticadreptului - o nouă perspectivă în percepția fenomenelor juridice, în vol. "Justiție, Stat de drept și cultură juridică", Universul Juridic Publishing House, Bucharest, 2011;

- Drăghici Andreea, Duminică Ramona, "Convergences and distinctions between moral and juridical order", in Agora International Journal of Juridical Sciences, no. 2/2011, available on www.juridicaljournal.univagora.ro;

- Duminică Ramona, The divine foundation of the law, in Agora International Journal of Juridical Sciences, no. 2/2011, available on www.juridicaljournal.univagora.ro;

- Măgureanu A. F., Principii legenerale ale dreptului, Universul Juridic Publishing House, Bucharest, 2011;

- Butculescu C.D., A systemic approach to legal cultures, in vol. "La Metamorphose de l'Etat en Europe", Universul Juridic Publishing House, Bucharest, 2010;

- Losano M. G., Marile sisteme juridice. Introducere în dreptul European și extraeuropean, All Beck Publishing House, Bucharest, 2005;

- Popescu Sofia, Teoria generală a dreptului, Lumina Lex Publishing House, Bucharest, 2003;

- Ferrari V., Note sull'alternativa del diritto contemporano, Sociologia del diritto, Revista quadrimente fondata da Renato Treves, XX/1993/1. 